5 Redfors A. Digoxin dosage and ventricular rate at rest and exercise in patients with atrial fibrillation. Acta Med Scand 1971;190:321-33.

6 McHaffie D, Smith D, O'Donnell T. Does digoxin control the heart rate on exercise in patients with atrial fibrillation? In: Oo TY, ed. Proceedings of the sixtcenth Singapore-Malaysia congress of medicine, Singapore, 1983. Singapore: Academy of Medicine, Singapore, 1983:158-6

Klein H, Pauzer H, De Signi E, David D, Kaplinsk E. The beneficial effects of verapamil in chronic atrial fibrillation. Arch Intern Med 1979;139:747-9.

8 Yahalom J, Klein H, Kaplinsky E. Beta adrenergic blockade as adjunctive ora therapy in patients with chronic atrial fibrillation. $556-7,642$

Duncan G, Johnson RH, Lambie DG, Whiteside EA. Evidence of vagal neuropathy in chronic alcoholics. Lancet 1980;ii:1053-7.

1 Smith TW, Butler VP, Haber E. Determination of therapeutic and toxic serum digoxin concentrations by radioimmunoassay. N Engl f Med 1969;281:1212-6.
12 Smith DA, O'Donnell TV. The time course during 36 weeks endurance training as determined with a new computerized method. Clin Sci 1984;67:229-36.

13 Bevington PR. Data reduction und error analysisfor the physical sciences. New York:

14 Astrand P-O, Rodahl K. Textbook of work physiology. 2nd ed. New York: McGraw Hill, 1977:187-90, 321

15 van der Walt WH, Wyndham $\mathrm{CH}$. An equation for prediction of energy expenditure of walking and running. I Appl Physiol 1973;34:559-67.

16 Moe GK, Farah AE. Digitalis and allied cardiac glycosides. In: Goodman L Gilman A,

17 Rowell LB. Human cardiovascular adjustments to exercise and thermal stress. Physiol Rev 1974;54:75-159.

(Accepted 24 September 1984)

\title{
Thyroxine, methimazole, and thyroid microsomal autoantibody titres in hypothyroid Hashimoto's thyroiditis
}

\author{
ROLF JANSSON, ANDERS KARLSSON, PER ANDERS DAHLBERG
}

\begin{abstract}
Ten hypothyroid patients with Hashimoto's thyroiditis were treated with methimazole $30 \mathrm{mg}$ in addition to thyroxine $0.15 \mathrm{mg}$ daily. Another 10 hypothyroid patients with Hashimoto's thyroiditis were given thyroxine $0.15 \mathrm{mg}$ alone. After 22 weeks of treatment significant decreases in thyroid microsomal autoantibody titres were observed in both groups $(p<0.01)$. There was no difference in the mean change in titre between the two groups. When the patients treated with methimazole were subsequently given thyroxine $0.15 \mathrm{mg}$ alone for a further 22 weeks no additional change in titre was observed.
\end{abstract}

The data suggest that thyroxine, by normalising serum thyroid stimulating hormone concentrations, may reduce the autoantigenic properties of the thyrocytes with a subsequent decrease in autoantibody titres.

\section{Introduction}

Treatment of Graves' thyrotoxicosis with thionamide drugs, such as methimazole, carbimazole, and propylthiouracil, is accompanied by a decrease in thyroid autoantibody titres. ${ }^{1-5}$ These thyrostatic drugs, which are known to be accumulated in the thyroid, ${ }^{6}$ have been suggested to have an immunosuppressive effect on antibody producing lymphocytes or antigen presenting monocytes located in the thyroid. ${ }^{4}{ }^{7}$ " We compared the effects of methimazole combined with thyroxine and of thyroxine alone on the titres of thyroid microsomal autoantibodies in hypothyroid patients with Hashimoto's thyroiditis. Both regimens were found to lower the antibody titres to the same extent.

\section{Subjects and methods}

Twenty patients (19 women and one man), who were referred to our outpatient thyroid clinic because of hypothyroidism, participated in the study after giving their informed consent. All patients had autoimmune goitrous thyroiditis (Hashimoto's thyroiditis), the diagnosis being based on the presence of serum thyroid microsomal autoantibodies and lymphocytic thyroiditis in fine needle aspiration biopsy specimens from the thyroid. The table shows the characteristics of the 20 patients.

The study, which was approved by the ethical committee of Uppsala University, was designed as follows (figure). Ten of the patients were treated with thyroxine and methimazole for 28 weeks (group 1). Thyroxine (Levaxin; Nyegaard, Oslo, Norway) was increased gradually by $0.05 \mathrm{mg}$ every second week to a final dose of $0.15 \mathrm{mg}$. Methimazole (Thacapzol; KabiVitrum, Stockholm, Sweden) was similarly increased by $10 \mathrm{mg}$ every second week to a final dose of $30 \mathrm{mg}$ daily. Both drugs were given by mouth three times a day. This treatment was given for another 20 weeks and then gradually withdrawn over four weeks by $0.05 \mathrm{mg}$ and $10 \mathrm{mg}$, respectively, every second week. After four weeks without treatment thyroxine alone was started again as in the initial treatment period. Another 10 patients (group 2) were given the same thyroxine treatment as group 1 , but methimazole was omitted.

Blood samples were drawn zero, six, 14, 22, 30, 38, 46, and 54 weeks after the start of treatment in group 1 , and thyroid function was consecutively analysed by routine radioimmunoassay methods. Similarly, blood samples were drawn zero, six, 14, 22, and 30 weeks after the start of treatment in group 2. One aliquot of serum from each sampling occasion was kept frozen at $-20 \mathrm{C}$. After completion of the study all aliquots were analysed in a single assay run for the titre of thyroid microsomal autoantibodies by a commercial haemagglutination method (Thymune-M; Wellcome, Beckenham, UK). Fine needle aspiration biopsies were performed and evaluated at the department of cytology in this hospital. Serum methimazole was determined with a gas chromatographic mass spectrometric method. ${ }^{6}$

Student's $t$ test for paired and unpaired data was used for statistical evaluation. The thyroid microsomal autoantibody titres were logarithmically transformed before calculations: $1: 50=1,1: 100=2,1: 200=3$, $\ldots 1: 409600=14$

\section{Results}

The figure shows the individual and mean thyroid microsomal autoantibody titres before and after 22 weeks of treatment in the two groups of patients. The mean thyroid microsomal autoantibody titre decreased significantly in both $(\mathrm{p}<0.01$ by paired $t$ test in both groups). In both groups the microsomal autoantibody titres decreased in eight patients and remained unchanged in two. The mean decrease was similar in the two groups (NS by $t$ test for groups).

In three patients treatment could not, for ethical reasons, be with-
ROLF JANSSON, MD, registrar

ANDERS KARLSSON, MD, associate professor

PER ANDERS DAHLBERG, $M D$, associate professor

Correspondence to: Dr R Jansson. 
drawn as planned after 28 weeks. In the remaining patients the mean thyroid microsomal autoantibody titre did not change in either group in the period after treatment. When thyroxine alone was subsequently given for another 22 weeks (figure) to patients in group 1 no significant change in mean thyroid microsomal autoantibody titre was observed.

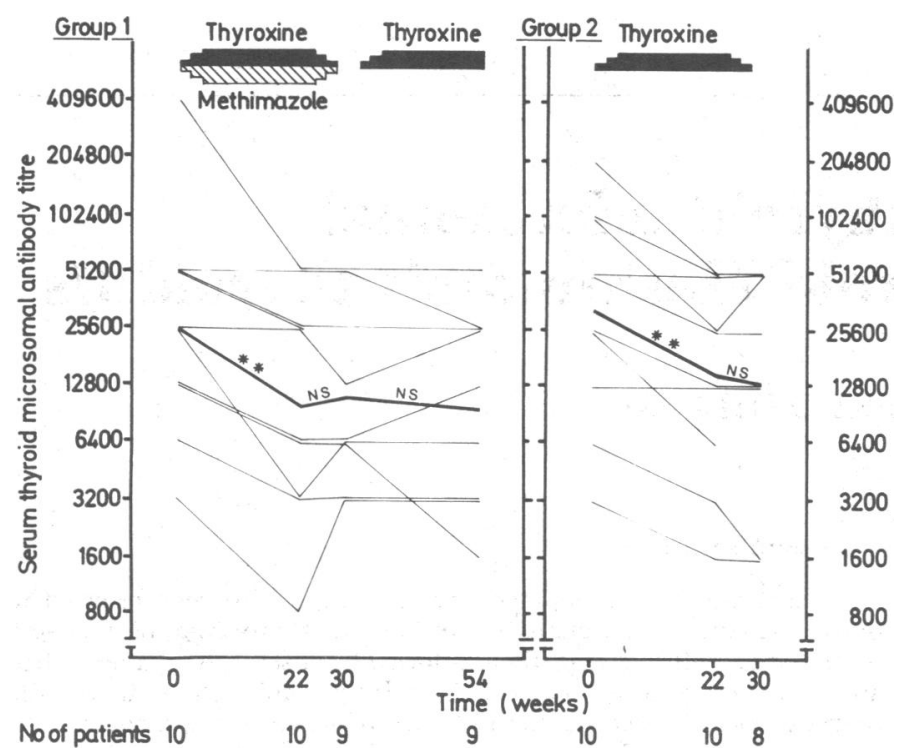

Individual ( $\longrightarrow$ ) and mean ( $\longrightarrow$ ) serum thyroid microsomal antibody titres in group 1 (treated with thyroxine and methimazole combined followed by thyroxine alone) and group 2 (treated with thyroxine alone). (Significance by paired $t$ test: ${ }^{* *} \mathrm{p}<0.01$.)

All patients had a raised serum thyroid stimulating hormone concentration before treatment (table), and this returned to normal during treatment in all cases. The concentrations of thyroid stimulating hormone (geometric mean) at the end of the first period of treatment were $2.0 \mathrm{mU} / 1$ and $1.9 \mathrm{mU} / 1$ in groups 1 and 2 , respectively. In the interval without treatment hypothyroidism recurred and the mean concentration of thyroid stimulating hormone, $32 \mathrm{mU} / 1$ and $27 \mathrm{mU} / 1$ in groups 1 and 2 respectively, reached the concentration observed before the study (NS by paired $t$ test in both groups).

Methimazole was detected in all serum samples obtained from patients in group 1, 22 weeks after the start of treatment with that drug. The mean (SEM) concentration of methimazole was $88(9) \mathrm{ng} /$ $\mathrm{ml}$. Seven of the patients in group 1 agreed to repeated fine needle aspiration thyroid biopsy in the interval without treatment, and lymphocytic thyroiditis was still present in all.

\section{Discussion}

In this study we found that hypothyroid patients with Hashimoto's thyroiditis treated with thyroxine to attain the euthyroid state showed decreased serum thyroid microsomal autoantibody titres. Addition of methimazole ( $30 \mathrm{mg}$ daily) had

Mean (SD) pretreatment data on patients with Hashimoto's thyroiditis. No significant differences were observed between the two groups

\begin{tabular}{|c|c|c|}
\hline Variable & $\begin{array}{l}\text { Patients receiving } \\
\text { combined thyroxine } \\
\text { and methimazole } \\
\qquad(\mathrm{n}=10)\end{array}$ & $\begin{array}{l}\text { Patients receiving } \\
\text { thyroxine alone } \\
(\mathrm{n}=10)\end{array}$ \\
\hline $\begin{array}{l}\text { Age, in years } \\
\text { Free thyroxine index* } \\
\text { Free triiodothyronine index }{ }^{\dagger} \\
\text { Thyroid stimulating hormone }(\mathrm{mU} / 1)_{+}^{+}\end{array}$ & $\begin{array}{l}44(17) \\
55(18) \\
1.4(0 \cdot 5) \\
32(13-81) \S\end{array}$ & $\begin{array}{l}48(10) \\
63(23) \\
1.5(0 \cdot 4) \\
22(10-48) \$\end{array}$ \\
\hline
\end{tabular}

Reference ranges: $* 67-153 ;+1 \cdot 2-2 \cdot 8 ; \ddagger \leqslant 8 \mathrm{mU} / 1$.

§Geometric mean (SD). no further effect on the titre changes. This last finding contradicts a previous report on patients with Hashimoto's thyroiditis, ${ }^{9}$ who were treated for 12 weeks with $45 \mathrm{mg}$ carbimazole (which through bioactivation, is converted to $27.5 \mathrm{mg}$ methimazole. ${ }^{10}$ ) Carbimazole was introduced when the patients were already receiving thyroxine, and it was reported to have the effect of lowering thyroid microsomal autoantibody titres. Although the designs of these studies were not identical, no obvious explanation exists for this discrepancy.

The view that antithyroid drugs are immunosuppressive in vivo is controversial. ${ }^{11}$ Immunosuppressive effects of methimazole in vitro on lymphocytes ${ }^{412}$ and monocytes ${ }^{7}{ }^{8}$ have generally been observed at drug concentrations higher than those measured in the thyroid. ${ }^{6}$ Furthermore, it has been shown that methimazole is not accumulated in lymphocytes from patients with Graves' disease. ${ }^{13}$ Moreover, in two studies methimazole was found to enhance lymphocyte proliferative responses to lectins, whereas propylthiouracil had a suppressive action. ${ }^{14}{ }^{15}$ Thus alternative explanations may be sought to explain the antibody reciucing effect of thyrostatic treatment in Graves' thyrotoxicosis and the similar effect observed in the present study. Possibly, thyroxine in hypothyroid patients with Hashimoto's thyroiditis, with consequent reduction in stimulatory thyroid stimulating hormone concentrations, alters the characteristics of the thyrocytes so that the "autoimmune signal" decreases. This would occur if, for instance, the amount of thyroid autoantigens were decreased or, alternatively, if HLA-DR antigenicity were reduced. Expression of HLA-DR antigens on thyroid cells in diseased but not in normal states was reported recently. ${ }^{16} 17$

Our data thus suggest that, in the management of patients with autoimmune disorders, immunosuppressive effects might be achieved not only by classic drugs acting directly on the immunocompetent cells but also by drugs altering the target cells within the diseased organ so that their autoimmune stimulus is reduced.

This work was supported by grants from Tore Nilson Foundation, Nordic Insulin Foundation, and the Swedish Medical Research Council (No 4996).

\section{References}

1 Pinchera A, Liberti P, Martino E, et al. Effects of antithyroid therapy on the long-acting thyroid stimulator and the antithyroglobulin antibodies. $\mathcal{F}$ Clin Endocrinol Metab 1969;29:231-8.

2 Fenzi GF, Hashizume K, Roudeboush CP, De Groot LJ. Changes in thyroidstimulating immunoglobulins during antithyroid therapy. $\mathcal{f}$ Clin Endocrinol Metab $1979 ; 48: 572-6$.

3 Teng CS, Yeung RTT. Changes in thryoid-stimulating antibody activity in Graves' disease treated with antithyroid drug and its relationship to relapse: a prospective study. I Clin Endocrinol Metab 1980;50:144-7.

4 McGregor AM, Petersen MM, McLachlan SM, Rooke P, Smith RB, Hall R. Carbimazole and $1980 ; \mathbf{3 0 3}: 302-7$.

5 Karlsson FA, Dahlberg PA. Thyroid stimulating antibodies (TSAb) in patients with Graves' disease undergoing antithyroid drug treatment-indicators of activity of disease. Clin Endocrinol 1981:14:579-85.

6 Jansson R, Dahlberg PA, Johansson H, Lindström B. Intrathyroidal concentrations of methimazole in patients with Graves' disease. $\mathcal{F}$ Clin Endocrinol Metab 1983;57:129-32.

7 Weetman AP, MCGregor AM, Hall R. Methimazole inhibits thyroid autoantibody production by an action on accessory cells. Clin Immunol Immunopathol $1983 ; 28: 39-45$

Weetman AP, Holt ME, Campbell AK, Hall R, McGregor AM. Methimazole and generation of oxygen radicals by monocytes: potential role in immuno-

McGregor AM, Ibbertson $\mathrm{HK}$, Smith BR, Hall R. Carbimazole and autoantibody synthesis in Hashimoto's thyroiditis. Br Med F 1980;281:968-9.

10 Jansson R, Dahlberg PA, Lindström B. Comparative bioavailability of carbimazole and methimazole. Int f Clin P'harmacol Ther Toxicol 1983;21:505-10.

11 Kendall-Taylor P. Are antithyroid drugs immunosuppressive? Br Med $\mathcal{F} 1984$;

288:509-11.
12 Weiss I, Davies TF. Inhitition of immunoglobulin-secreting cells by antithyroid drugs, f Cli: Endocrinol Metab 1981;53:1223-8.

13 Shewring GS, Lazarus $\mathrm{JH}$. The accumulation of methimazole by human and rat lymphocytes. Acta lindocrinol (Copenh) 1983:102:68-70.

14 Hallengren B, Forsgren A, Melander A. Effects of antithy roid drugs on lymphocyte function in vitro. F Clin Endocrinol Metab 1980:51:298-301.

15 Okabe N, Inoue K, Mori R. Effects of antithyroid drugs on lymphocyte proliferative responses to lectins: relationship between insulin autoimmune syndrome
and methimazole. $\mathcal{F}$ Clin Lab Immunol $1983 ; \mathbf{1 1}: 167-71$.

16 Hanafusa $T$, Puiol-Borrell R, Chiovato L, Russel RCG, Doniach D, Bottazzo Gi. Aberrant expression of HLA-DR antigen on thyrocytes in Graves' disease relevance for autoimmunity. Lancet 1983;ii:1111-5.

17 Jansson R, Karlsson A, Forsum U. Intrathyroidal HLA-DR expression and T lymphocyte phenotypes in Graves thyrotoxicosis, Hashimoto's thy roiditis and nodular colloid goitre. Clin Exp Immunol (in press).

(Accepted 8 October 1.984) 